\title{
p21 and p53 Expression in Young Breast Cancer Patients in Bali
}

\author{
N P Sriwidyani ${ }^{1}$, N W Winarti ${ }^{2}$ \\ Anatomical Pathology Department, Faculty of Medicine Udayana University/Sanglah Public General Hospital
}

\begin{abstract}
Young breast cancer is rare and related to a more progressive disease. In Bali, incidence of early onset breast carcinoma is quite frequent. 553 is an important cell cycle regulator and stop cell cycle via transcription of p21. Over expression of p53 in breast cancer is related to a bad prognosis. This study aims to evaluate correlation between p21 expression and p53 expression and clinicopathologic characteristics in young breast cancer patients in Bali. A total 25 paraffin-embedded samples of young breast carcinoma were examined. The expression of $p 53$ and p21 proteins was analyzed by immunohistochemistry. Clinicopathologic data was from histopathology report and medical report. In this study, p21 expression in young breast carcinoma has no significant correlation with p53 expression and other clinicopathologic parameters.
\end{abstract}

Keywords: p21, p53, young, breast cancer, Bali

\section{Introduction}

Breast cancer is the most common malignancy in woman. ${ }^{1}$ In western countries, most of breast cancer occurs in elderly, meanwhile early breast cancer is rare and related to a certain hereditary genetic alteration. In Asian women, early breast cancer is quite frequent and related to more progressive disease. $^{2,3}$ Breast carcinoma is heterogenic disease with varies clinical manifestation. Many conventional clinicopathologic approach and molecular method is used to predict prognosis and response to treatment.

p53 is a transcription factor with an important role in regulation of cell cycle, DNA repair, apoptosis, and angiogenesis. p53 protein will stop cell cycle in G1/S checkpoint via transcription of p21 (a cyclin-dependent kinase inhibitor) and allowing repair of damaged DNA. If DNA repair is fail, p53 will initiate transcription of proapoptotic protein and induce apoptosis of damaged cell. ${ }^{4}$ In breast cancer, overexpression of p53 is related to a bad prognosis. $^{5,6,7}$

This study will find out the correlation of p21 expression with p53 expression and known clinicopathologic variables in young breast carcinoma patients in Bali.

\section{Material and Methods}

\section{Specimens}

Slides and paraffin embedded tissue blocks from 25 patients breast carcinoma aged $\leq 40$ year old were retrieved from the histopathology archives in Anatomical Pathology Laboratory of Sanglah Public General Hospital in the year 2013-2014. Clinical data were from the medical report.

\section{Histopathologic evaluation}

The slides from these cases were reviewed and histopathologic diagnoses in the histopathologic reports were confirmed independently by two pathologists (NPS, NWW). The histologic type of tumor was based on WHO criteria. The grading system was using Bloom and Richardson's three-tire scheme based on tubular formation, pleomorphism and mitosis index.

\section{Immunohistochemistry and interpretation}

Four $\mu \mathrm{m}$ thickness tissue sections from each case were prepared for immunostaining. After overnight incubation in a $40^{\circ} \mathrm{C}$ oven and deparaffinization, tissue sections were treated with $3 \%$ hydrogen peroxide for 20 minutes. Following heat epitope retrieval in citric buffer for 20 minutes in room temperature, the slides were incubated with one of the following primary antibodies: anti-human p53, p21, Estrogen receptor (ER) and Human Growth Factor Receptor 2 (HER2) (Lab Vision, USA). The colour was visualized by DAB as chromogen.

Immunostaining for each of the markers were interpreted by two pathologists independently (NPS, NWW). p53, p21, and ER were classified as positive if there were nuclear staining of $\geq 10 \%$ tumor cells. A positive HER2 staining was determined by strong sircumferential membranous staining in $\geq 30 \%$ tumor cells.

\section{Statistical analysis}

Descriptive statistics were calculated. Chi square test was used to assess the association between p21 expression with p53 expression and other clinicopathologic parameters. P value less than 0.05 was considered significant. All statistical analyses were performed using SPSS 13.0.

\section{Results and Discussion}

In 2013-2014, there were 153 cases of breast carcinoma, with 30 patients with age $\leq 40$ year. Twenty five cases were eligible for this study with age range was from 24 to 40 year old. The clinicopathological features and p53 and p21 immunohistochemistry profile of 25 young breast cancer cases are summarized in Table 1.

From 25 cases, most of the cases with large tumor (T3 and T4; 17 of 25 cases (68\%)), positive nodal status (15 of 25 cases $(60 \%)$ ), and late stage (III and IV; 21 of 25 cases $(84 \%))$. The possible reason for these findings is that young cancer cases tend to be more aggressive than breast cancer in adult women and elderly. ${ }^{3}$ Another important reason is low awareness of young breast cancer patients in Bali to seek 


\section{International Journal of Science and Research (IJSR) \\ ISSN (Online): 2319-7064 \\ Index Copernicus Value (2013): 6.14 | Impact Factor (2014): 5.611}

medical attention if there is any abnormality found in their breast.

Table 1: Clinicopathological characteristics and p53 expression related to $\mathrm{p} 21$ profile

\begin{tabular}{|c|c|c|c|}
\hline \multirow[t]{2}{*}{ Characteristic } & \multicolumn{2}{|c|}{ P21 } & \multirow[t]{2}{*}{$P$ value } \\
\hline & $\begin{array}{c}\text { Positive } \\
(\mathrm{n}=5)\end{array}$ & $\begin{array}{c}\text { Negative } \\
(n=20)\end{array}$ & \\
\hline \multicolumn{4}{|l|}{ Tumor size } \\
\hline $\mathrm{T} 1$ & 0 & 3 & \multirow[t]{4}{*}{0.200} \\
\hline $\mathrm{T} 2$ & 0 & 5 & \\
\hline T3 & 4 & 6 & \\
\hline $\mathrm{T} 4$ & 1 & 6 & \\
\hline \multicolumn{4}{|l|}{ Nodal status } \\
\hline Positive & 4 & 11 & \multirow{2}{*}{0.307} \\
\hline Negative & 1 & 9 & \\
\hline \multicolumn{4}{|l|}{ Stage } \\
\hline I & 0 & 2 & \multirow[t]{4}{*}{0.754} \\
\hline II & 0 & 2 & \\
\hline III & 4 & 13 & \\
\hline IV & 1 & 3 & \\
\hline \multicolumn{4}{|l|}{ Histologic type } \\
\hline IDC & 4 & 17 & \multirow[t]{3}{*}{0.313} \\
\hline ILC & 0 & 2 & \\
\hline Other & 1 & 1 & \\
\hline \multicolumn{4}{|l|}{ Grade } \\
\hline 1 & 0 & 1 & \multirow[t]{3}{*}{0.190} \\
\hline 2 & 1 & 12 & \\
\hline 3 & 4 & 7 & \\
\hline \multicolumn{4}{|l|}{ ER/HER2 status } \\
\hline ER+/HER2- & 2 & 9 & \multirow[t]{4}{*}{0.518} \\
\hline ER+/HER2+ & 2 & 3 & \\
\hline ER-/HER2+ & 0 & 4 & \\
\hline ER-/HER2- & 1 & 4 & \\
\hline \multicolumn{4}{|l|}{ P53 status } \\
\hline Positive & 2 & 12 & \multirow[t]{2}{*}{0.378} \\
\hline Negative & 3 & 8 & \\
\hline
\end{tabular}

Most of the cases are ductal histology (21 of 25 cases (84\%)), high grade tumor (grade 2 and 3; 24 of 25 cases (96\%)) and ER-positive tumor (16 of 25 cases (64\%)). This finding also consistent with Yoshida et $a^{3}$ and Azim et al ${ }^{8}$ studies.

p53 mutation are found in many cases of malignancy, as well as in breast carcinoma. In about $30 \%$ cases of breast carcinoma show TP53 mutation. ${ }^{7}$ This gene mutation is related to worse prognosis. Tiezzi et al (207) also found p53 mutation as a treatment response predictor in breast cancer. ${ }^{9}$

p53 protein has an important role in maintaining genomic integrity. This protein is a transcription factor that regulates many gene expression involved in control of cell cycle, DNA repair, apoptosis and angiogenesis. If there is a breakdown DNA, p53 protein will be activated and increase protein transcription. p21 protein (a cyclin-dependent kinase inhibitor) will stop cell cycle temporarily in G1/S checkpoint and give a chance for DNA repair. If this repair failed, p53 will increase BAX protein (a proapoptotic molecule) transcription and stimulate apoptosis of unrepaired cell. Cell with p53 mutation, if there is an abnormal DNA, there will be no p53-dependent genes activation, no DNA repair, no cellular aging, and mutant cell that suffered from any additional mutation will implicate to a malignant progression. $^{4}$
In this study, p53 expression has no significant correlation with p21 expression $(\mathrm{p}=0.378)$. Although theoretically p53 as a guardian of genome integrity trough increasing of transcription of p21 protein, in young breast cancer cases, p53 protein might work trough p21-independent pathway. There is no correlation between p21 expression with clinicopathologic characteristics.

\section{Conclusion}

Breast carcinomas in young woman tend to be more aggressive. p53 expression in young breast carcinoma has no significant correlation with p21 expression.

\section{References}

[1] Ferlay J, Shin HR, Bray F, Forman D, Mathers C, Parkin DM. Estimates of worldwide burden of cancer in 2008: Globocan 2008. Int $J$ Cancer. 2010;127(12):2893-917.

[2] Foo CS, Su D, Chong CK, Chng HC, Tay KH, Low SC, Tan SM. Breast cancer in young Asian women: study on survival. ANZ J Surg. 2005;75:566-72.

[3] Yoshida M, Shimizu C, Fukutomi T, Tsuda H, Kinoshita T, Tanaka SA, et al. Prognostic factors in young Japanese women with breast cancer: prognostic value of age at diagnosis. Jpn J Clin Oncol. 2011; 41(2):180-189.

[4] Stricker TP, Kumar V. Neoplasia. In: Kumar V, Abbas AK, Fausto N, Aster JC. Pathologic basis of disease. $8^{\text {th }}$ ed. Sauders Elsevier. Philadelphia. 2010:259-330.

[5] Gasco M, Shami S, Crook T. The p53 pathway in breast cancer. Breast Cancer Res. 2002;4:70-76.

[6] Lacroix M, Toillon RA, Leclercq G. p53 and breast cancer. Endocrine-Related Cancer. 2006;13:293-325.

[7] Rossner P, Gammon MD, Zhang YJ, Terry MB, Hibshoosh H, Memeo L, et al. Mutations in p53, p53 protein expression and breast cancer survival. J Cell Mol Med. 2009;13(9B):3847-3857.

[8] Azim HA, Partridge AH. Biology of breast cancer in young women. Breast Cancer Research. 2016;16(427):1-9

[9] Tiezzi DG, Andrade JM, Silva AR, Zola FE, Marana HR, Tiezzi MG. HER2, p53, p21 and hormonal receptors proteins expressions as predictive factors of response and prognosis in locally advanced breast cancer treated with neoadjuvant docetaxel plus epirubicin combination. BMC Cancer.2007;7:1-10.

\section{Author Profile}

Ni Putu Sriwidyani is Anatomical Pathology Department, Faculty of Medicine Udayana University/Sanglah Public General Hospital 